\title{
HUBUNGAN TINGKAT PENGETAHUAN IBU TENTANG IMUNISASI DPT PADA BAYI DENGAN PERILAKU PENCEGAHAN PENYAKIT DIFTERI PERTUSIS DAN TETANUS DI PUSKESMAS KORPRI BANDAR LAMPUNG TAHUN 2020
}

\author{
Ringgo Alfarisi ${ }^{1}$ Jordy Oktobiannobel ${ }^{2}$ Tri Wibowo Julianto $^{3}$ \\ Email: triwibowojulianti07@gmail.com ${ }^{3}$ \\ Fakultas Kedokteran Universitas Malahayati ${ }^{1,2}$ \\ Program Studi Kedokteran Universitas Malahayati ${ }^{3}$
}

\begin{abstract}
DPT immunization is the basic immunization used to prevent diphtheria pertussis and tetanus. According to data from the Bandar Lampung City Health Office from 30 health centers in Bandar Lampung, the Korpri Puskesmas in Sukarame District is the health center with the lowest complete basic immunization coverage, which is $60.8 \%$ in 2015. The low immunization coverage rate is inseparable from health behavior and parental knowledge about DPT immunization. Purpose of this study to determine the relationship between the level of mother's knowledge about DPT immunization in infants with the prevention behavior of diphtheria pertussis and tetanus at the Korpri Puskesmas Bandar Lampung in 2020. This study used an observational and analytic type of study with a cross sectional approach and a questionnaire interview method. The sample used in this study were mothers who had babies in the work area of the Korpri Bandar Lampung Community Health Center in 2020. Data analysis used Chi-Square. The result It is known that 7 mothers $(77.8 \%)$ have bad knowledge about DPT immunization and bad behavior towards DPT disease prevention, as many as 2 mothers (22.2\%) have bad knowledge about DPT immunization and good behavior towards DPT disease prevention. A total of 28 mothers (33.3\%) had good knowledge about DPT immunization and bad behavior towards DPT disease prevention, as many as 56 mothers (66.7\%) had good knowledge about DPT immunization and good behavior towards DPT disease prevention. Chi-square test results obtained $p$-value $=0.024(p \leq 0.05)$, which means that there is a relationship between the level of maternal knowledge and the prevention behavior of diphtheria, pertussis and tetanus. There is a significant relationship between the level of maternal knowledge about DPT immunization in infants with the prevention behavior of diphtheria pertussis and tetanus at the Korpri Puskesmas Bandar Lampung in 2020 with a pvalue $=0.024(p \leq 0.05)$.
\end{abstract}

Keywords : Knowledge Level, Behavior, DPT Immunization.

\begin{abstract}
Abstrak
Imunisasi DPT merupakan imunisasi dasar yang digunakan untuk mencegah terjadinya penyakit difteri, pertusis dan tetanus. Menurut data dari Dinas Kesehatan Kota Bandar Lampung dari 30 puskesmas di Bandar Lampung, Puskesmas Korpri Kecamatan Sukarame merupakan puskesmas dengan cakupan imunisasi dasar lengkap terendah yaitu sebesar $60,8 \%$ pada tahun 2015. Angka cakupan imunisasi yang masih rendah tersebut tidak terlepas dari perilaku Kesehatan dan pengetahuan orangtua tentang imunisasi DPT. Tujuan penelitian ini adalah untuk mengetahui hubungan tingkat pengetahuan ibu tentang imunisasi DPT pada bayi dengan perilaku pencegahan penyakit difteri, pertusis dan tetanus di Puskesmas Korpri Bandar Lampung Tahun 2020. Metode penelitian ini menggunakan metode jenis observasional dan bersifat analitik dengan pendekatan potong lintang atau "cross sectioanal" serta metode wawancara dengan kuesioner. Sampel yang digunakan pada penelitian ini adalah ibu yang memiliki bayi di wilayah kerja Puskesmas Korpri Bandar Lampung Tahun 2020. Analisa data menggunakan Chi-Square. Hasilnya adalah diketahui 7 ibu $(77,8 \%)$ memiliki pengetahuan buruk mengenai imunisasi DPT dan perilaku yang buruk terhadap pencegahan penyakit DPT, sebanyak 2 ibu (22,2\%) memiliki pengetahuan buruk mengenai imunisasi DPT dan perilaku yang baik terhadap pencegahan penyakit DPT. Sebanyak $28 \mathrm{ibu}(33,3 \%)$ memiliki pengetahuan baik tentang imunisasi DPT dan perilaku yang buruk terhadap pencegahan penyakit DPT, sebanyak $56 \mathrm{ibu}(66,7 \%)$ memiliki pengetahuan baik tentang imunisasi DPT dan perilaku yang baik terhadap pencegahan penyakit DPT. Hasil uji chi-square didapatkan nilai $p$-value $=0,024(p \leq 0,05)$ yang berarti terdapat hubungan antara tingkat pengetahuan ibu dengan perilaku pencegahan penyakit difteri, pertusis dan tetanus. Terdapat hubungan yang bermakna antara tingkat pengetahuan ibu tentang imunisasi DPT pada bayi dengan perilaku
\end{abstract}


pencegahan penyakit difteri, pertusis dan tetanus di puskesmas korpri bandar lampung tahun 2020 dengan nilai $p$-value $=0,024(p \leq 0,05)$.

Kata Kunci : Tingkat Pengetahuan, Perilaku, Imunisasi DPT

\section{PENDAHULUAN}

Imunisasi merupakan prosedur yang dilakukan untuk memberikan kekebalan tubuh terhadap suatu penyakit dengan memasukkan vaksin ke dalam tubuh seseorang sehingga tubuh dapat tahan terhadap penyakit, baik yang sedang mewabah mauapun yang berbahaya bagi seseorang. Imunisasi berasal dari kata imun yang berarti kebal atau resisten. Imunitas terhadap suatu penyakit hanya akan memberikan kekebalan atau resistensi pada penyakit itu saja sehingga untuk terhindar dari penyakit lain diperlukan imunisasi lainnya (Anggraeni, 2015). Imunisasi adalah salah satu cara untuk memberikan kekebalan pada bayi dan anak terhadap berbagai penyakit, sehingga dengan imunisasi diharapkan bayi dan anak tetap tumbuh dalam keadaan sehat (Hidayat, 2008).

Imunisasi DPT merupakan imunisasi dasar yang digunakan untuk mencegah terjadinya penyakit difteri, pertusis, dan tetanus. Imunisasi dasar DPT diberikan 3 kali sejak umur 2 bulan, 4 bulan dan 6 bulan. Kasus tetanus pada bayi baru lahir di dunia merupakan penyebab penting dari kematian bayi, sekitar 180.000 kehidupan diseluruh dunia setiap tahun, hampir secara eksklusif dinegara-negara berkembang. Meskipun sudah dicegah dengan imunisasi dan vaksin tetanus pada bayi tetap sebagai masalah kesehatan masyarakat di 48 negera terutama di Asia dan Afrika (Anariyusmi, 2010 dalam Mustari, 2013).

\section{Data World Health Organization} (WHO) tahun 2011 menyebutkan sekitar 1 juta kasus tetanus dilaporkan dari seluruh dunia pada tahun 2010, dan lebih dari $50 \%$ kematian akibat penyakit ini terjadi pada neonatus. Di Indonesia, kasus Tetanus neonatorum pada tahun 20072011 menyebabkan kematian bayi sekitar 50-60\%. Kasus Tetanus Neonatorum tahun 2011 yang paling banyak adalah di Provinsi Banten sebesar 38 kasus, Provinsi Jawa timur sebanyak 22 kasus, kemudian Provinsi Kalimantan Barat sebesar 13 kasus (Kemenkes RI, 2012 dalam Aprida, et all 2015).

Berdasarkan Pusat Data dan Informasi Provinsi Lampung tahun 2014 cakupan imunisasi di Indonesia sebesar 48,4\% dengan cakupan imunisasi provinsi lampung sebesar 54,5\%. Dari 15 kabupaten di Provinsi lampung, Bandar lampung memiliki cakupan imunisasi terendah yaitu sebesar 36\% (Pusdatin Prov. lampung, 2014). Menurut data dari Dinas Kesehatan Kota Bandar Lampung 
dari 30 Puskesmas di Bandar Lampung, Puskesmas Korpri Kecamatan Sukarame merupakan Puskesmas dengan cakupan imunisasi dasar lengkap terendah yaitu sebesar 60,8\% pada tahun 2015 dan sebesar 46\% pada tahun 2017. Angka cakupan imunisasi yang masih rendah tersebut tidak terlepas dari perilaku kesehatan dan pengetahuan orang tua tentang imunisasi DPT (Dinkes Kota Bandar Lampung, 2015).

Faktor - faktor pada ibu seperti pengetahuan, pendidikan, pekerjaan, sikap dan sebagainya akan sangat mempengaruhi pemberian imunisasi pada anak. Pengetahuan ibu tentang pentingnya imunisasi akan menjadi motivasi ibu membawa anaknya untuk di imunisasi. Beberapa masalah terkait pengetahuan ibu seperti ketidaktahuan ibu akan pentingnya imunisasi, ketidaktahuan waktu yang tepat untuk mendapatkan imunisasi dan ketakutan akan efek samping yang ditimbulkan imunisasi menjadi penyebab anak terkena PD3I (Kemenkes RI, 2013).

Dengan demikian, Berdasarkan latar belakang tersebut peneliti tertarik untuk mengetahui apakah ada hubungan antara tingkat pengetahuan ibu tentang imunisasi DPT pada bayi dengan perilaku pencegahan penyakit difteri, pertusis dan tetanus di Puskesmas Korpri Bandar Lampung tahun 2020. Permasalahan dalam penelitian ini adalah mencari hubungan tingkat pengetahuan ubu tentang imunisasi DPT pada bayi dengan perilaku pencegahan penyakit difteri, pertusis dan tetanus di Puskesmas Korpri Bandar Lampung tahun 2020.

\section{METODE PENELITIAN}

Metode penelitian ini menggunakan rancangan penelitian jenis observasional dan bersifat analitik, dengan pendekatan potong lintang atau "cross sectional" dan metode wawancara dengan kuesioner. Penelitian ini dilakukan untuk melihat hubungan tingkat pengetahuan ibu tentang imunisasi DPT pada bayi dengan perilaku pencegahan penyakit difteri, pertusis dan tetanus di Puskesmas Korpri Bandar Lampung tahun 2020.

Penelitian ini dilaksanakan pada bulan September 2020. Populasi dalam penelitian ini adalah seluruh ibu yang membawa bayi untuk imunisasi berjumlah 122 orang di Puskesmas Korpri Bandar Lampung tahun 2020. Sampel pada penelitian ini diambil dengan menggunakan Teknik purposive sampling dengan rumus slovin sebanyak 93 orang. Variable penelitian ini yaitu tingkat pengetahuan ibu tentang imunisasi DPT sebagai variable independent dan perilaku pencegahan penyakit difteri, pertusis dan tetanus sebagai variable dependen. 
Penelitian ini dilakukan pada seluruh ibu yang membawa bayi nya untuk imunisasi di wilayah kerja puskesmmas korpri bandar lampung.

Data penelitian diolah dengan program SPSS dengan menggunakan analisis univariat untuk menjabarkan tabel distribusi variabel penelitian, kemudian dilanjutkan analisis bivariat dengan uji Chi Square untuk mengetahui hubungan tingkat pengetahuan ibu tentang imunisasi DPT dengan perilaku pencegahan penyakit DPT. Pengujian analisis dengan tingkat kesalahan 5\% apabila didapatkan nilai $p \leq 0,05$ maka Ho ditolak, dan $\mathrm{Ha}$ diterima yaitu terdapat hubungan bermakna antara dua variabel yang diuji.

\section{HASIL PENELITIAN DAN}

\section{PEMBAHASAN}

\section{Analisis Univariat}

Tabel 1. Distribusi Frekuensi Tingkat Pengetahuan Ibu Tentang Imunisasi DPT

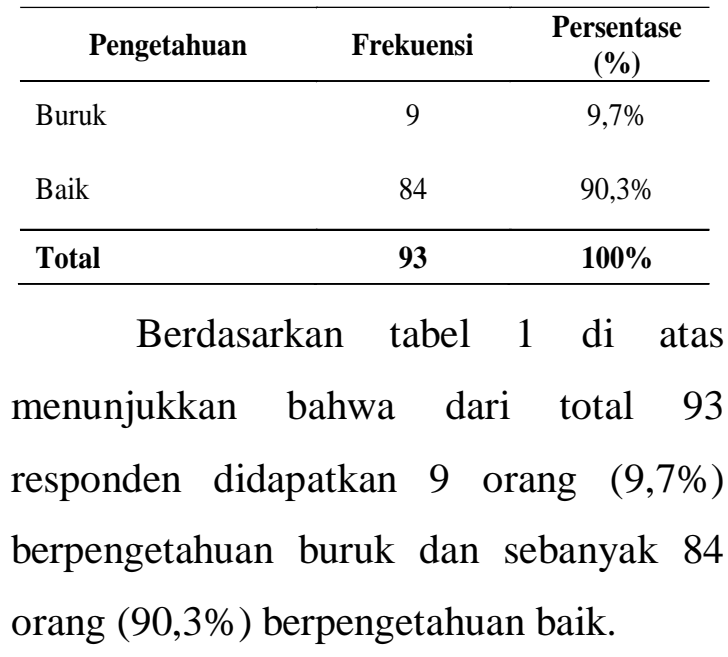

Tabel 2. Distribusi Frekuensi Perilaku Pencegahan Penyakit Difteri Pertusis dan Tetanus

\begin{tabular}{lcc}
\hline \multicolumn{1}{c}{ Perilaku } & Frekuensi & Persentase (\%) \\
\hline Buruk & 35 & $37,6 \%$ \\
Baik & 58 & $62,4 \%$ \\
\hline Total & $\mathbf{9 3}$ & $\mathbf{1 0 0 \%}$ \\
\hline
\end{tabular}

Berdasarkan tabel 2 di atas menunjukkan bahwa dari total 90 responden didapatkan 35 orang $(37,6 \%)$ berperilaku buruk dan sebanyak 58 orang $(62,4 \%)$ berperilaku baik.

\section{Analisis Bivariat}

Tabel 3. Hubungan Tingkat Pengetahuan Ibu Tentang Imunsisasi DPT dengan Perilaku Pencegahan DPT

\begin{tabular}{|c|c|c|c|c|c|c|c|}
\hline \multirow{3}{*}{ Tingkat Pengetahuan } & \multicolumn{4}{|c|}{ Perilaku } & \multirow{2}{*}{\multicolumn{2}{|c|}{ Total }} & \multirow{3}{*}{ P. value } \\
\hline & \multicolumn{2}{|c|}{ Buruk } & \multicolumn{2}{|c|}{ Baik } & & & \\
\hline & N & $\%$ & $\mathrm{~N}$ & $\%$ & N & $\%$ & \\
\hline Buruk & 7 & $77,8 \%$ & 2 & $22,2 \%$ & 9 & $100 \%$ & \\
\hline Baik & 28 & $33,3 \%$ & 56 & $66,7 \%$ & 84 & $100 \%$ & 0,024 \\
\hline Total & 35 & $100 \%$ & 58 & $100 \%$ & 93 & $100 \%$ & \\
\hline
\end{tabular}

Berdasarkan tabel 3 diketahui bahwa sebanyak 7 ibu $(77,8 \%)$ memiliki pengetahuan buruk mengenai imunisasi DPT dan Perilaku yang buruk terhadap pencegahan penyakit DPT, sebanyak $2 \mathrm{Ibu}$ $(22,2 \%)$ memiliki pengetahuan buruk mengenai imunisasi DPT dan Perilaku yang baik terhadap pencegahan penyakit DPT. Sebanyak 28 ibu $(33,3 \%)$ Ibu memiliki pengetahuan baik mengenai imunisasi DPT dan Perilaku yang buruk terhadap pencegahan penyakit DPT, sebanyak $56 \quad(66,7 \%)$ ibu memiiki pengetahuan baik mengenai imunisasi 
DPT dan Perilaku yang baik terhadap pencegahan penyakit DPT.

Hasil analisis uji Chi Square dengan tingkat kesalahan 5\% menggunakan SPSS 22.0 didapatkan $p$-value $=0,024(p \leq$ 0,05) menunjukkan bahwa Ho ditolak yang artinya terdapat hubungan yang bermakna antara tingkat pengetahuan ibu tentang imunisasi DPT dengan perilaku pencegahan penyakit difteri, pertusis dan tetanus di Puskesmas Korpri Bandar Lampung tahun 2020.

Pada penelitian ini didpatkan menunjukkan hasil tingkat pengetahuan ibu tentang imunisasi DPT berdasarkan kategori pengetahuan yaitu: ibu dengan pengetahuan buruk sebanyak 9 orang (9.7\%), dan ibu dengan pengetahuan baik sebanyak 84 orang $(90.3 \%)$. Hal tersebut disebabkan telah cukup efektifnya pemberian konseling oleh petugas kesehatan khususnya bidan terhadap ibu yang mengimunisasikan DPT Combo di puskesmas kopri. Pemberian konseling tersebut meliputi pengertian, efek samping, cara penanganan, dan pengobatan. Pemberian konseling tersebut berpengaruh terhadap peningkatan pengetahun ibu tentang imunisasi DPT Combo. Pendidikan seseorang mempengaruhi cara pandangnya terhadap diri dan lingkungannya, sehingga akan berbeda sikap orang yang berpendidikan lebih tinggi dan berpendidikan rendah (Wawan, 2010).

Pada penelitian ini didapatkan bahwa sebanyak 58 ibu (62.4\%) memiliki perilaku yang baik terhadap pencegahan DPT dan sebanyak 35 ibu (37.6\%) yang memiliki perilaku buruk terhadap pencegahan DPT. Penelitian ini sejalan dengan penelitian yang dilakukan oleh muryani menunjukan bahwa perilaku pencegahan penyakit difteri mayoritas berperilaku baik yaitu 58 orang $(84,1 \%)$. Mayoritas responden berperilaku baik, yang akan berpengaruh terhadap perilakunya dalam pencegahan penyakit difteri. Selain umur, pendidikan, pekerjaan dan pendapatan ibu, perilaku baik ini juga dapat dipengaruhi oleh tradisi masyarakat setempat yang selalu berbaur dan bersosialisasi dengan sesama warga masyarakat dalam bentuk kegiatan sosial, sehingga dalam pergaulan masyarakat akan membawa pengaruh terhadap individu tersebut. Kegiatankegiatan sosial seperti pengajian, arisan, PKK yang dilakukan oleh ibu-ibu tersebut membawa pengaruh positif. Selain untuk bersilaturahmi, para ibu-ibu juga saling berbagi pengetahuan, informasi dan pengalaman dalam berbagai hal, termasuk tentang penyakit difteri. Hal ini sesuai dengan penelitian Handayani bahwa pengetahuan tentang sesuatu hal 
menyebabkan orang akan besikap positif terhadap hal tersebut, selanjutnya sikap yang positif akan mempengaruhi niat untuk ikut dalam suatu kegiatan. Sehingga semakin baik tingkat pengetahuan ibu tentang difteri maka semakin baik pula perilaku pencegahan penyakit difteri (Muryani, 2013).

Hasil analisis antara pengetahuan ibu dengan periaku pencegahan penyakit DPT diperoleh nilai $\mathrm{p}$-value $=0,024$ dengan nilai $\mathrm{OR}=7.00$. Hal ini menunjukan bahwa penelitian pada tabel 4.3 terdapat hubungan positif yang signifikan antara tingkat pengetahuan ibu tentang imunisasi DPT pada bayi dengan periaku pencegahan penyakit DPT di puskesmas Korpri bandar Lampung 2020. Hasil tersebut sesuai dengan hipotesis yang diajukan dalam penelitian ini yaitu terdapat hubungan positif antara tingkat pengetahuan dengan perilaku pencegahan penyakit DPT.

Hasi peneitian ini sesuai dengan penelitian yang teah dilakukakan sebelumnya oleh Muryani et all. (2013) yang juga memperoleh hasil bahwa terdapat hubungan yang signifikan antara tingkat pengetahuan ibu tentang difteri dengan perilaku pencegahan penyakit difteri, semakin baik tingkat pengetahuan maka semakin baik periaku pencegahannya.
Hal ini sesuai dengan teori Notoatmodjo (2013), bahwa pengetahuan merupakan faktor predisposisi terbentuknya perilaku, dengan pengetahuan akan menimbulkan kesadaran dan akhirnya akan menyebabkan orang berperilaku sesuai dengan pengetahuan yang dimilikinya. Pengetahuan yang diperoleh secara baik akan membentuk perilaku yang baik pula. Masih menurut Notoatmodjo (2003), bahwa perilaku yang disadari oleh pengetahuan, kesadaran, dan sikap yang positif, maka perilaku tersebut akan bersifat langgeng (long lasting), sebaliknya apabila prilaku itu tidak didasari oleh pengetahuan dan kesadaran maka tidak akan berlangsung lama.

Hasil penelitian ini juga sejalan dengan teori dalam Notoatmodjo (2007), menyatakan bahwa kecenderungan seseorang yang berpengetahuan tinggi akan cenderung mempunyai perilaku yang baik, dalam bidang kesehatan dalam hal ini yaitu mengimunisasikan anaknya.

Hal tersebut menunjukkan bahwa pengetahuan ibu mempengaruhi status imunisasi pada bayinya, dimana bayi yang mempunyai ibu dengan pengetahuan tentang imunisasi yang baik akan mempunyai status imunisasi dasar yang lengkap dibandingkan dengan ibu yang berpengetahuan kurang baik terhadap 
imunisasi. Dimana penelitian ini sesuai dengan penelitian yang dilakukan Bofarraj (2011), yang meneliti tentang pengetahuan, sikap dan praktek ibu dalam pemberian imunisasi pada bayi. Dimana sikap yang negatif berupa pengetahuan yang kurang, berpengaruh terhadap kelengkapan imunisasi.

Berdasarkan hasil penelitian didapatkan masih terdapat beberapa ibu yang mempunyai pengetahuan yang baik dengan perilaku pencegahan penyakit difteri, pertusis dan tetanus nya masih buruk, kemungkinan ada beberapa faktor yang mempengaruhi.

Sebelum seseorang mengadopsi perilaku di dalam diri seseorang tersebut terjadi proses yang berurutan, yaitu kesadaran (awareness) yang artinya dimana orang tersebut menyadari dalam arti mengetahui terlebih dahulu terhadap stimulus, dalam hal ini ibu yang mengetahui dan menyadari berbagai hal tentang pentingnya perilaku pencegahan penyakit difteri, pertusis dan tetanus, setelah itu ibu mengetahui dan menyadari hal tersebut maka timbul ketertarikan (interest), yaitu ibu tertarik untuk melakukan perilaku pencegahan penyakit difteri, pertusis dan tetanus sesuai dengan informasi yang diketahui sebelumnya. Selanjutnya dengan melakukan evaluasi (evaluation) atau menimbang-nimbang baik dan tidaknya stimulus tersebut bagi dirinya atau dalam hal ini adalah subjek mulai menunjukkan perilaku terhadap objek, artinya ibu mulai berpikir untuk menjaga kesehatan anaknya dengan menimbang baik dan buruknya dengan perilaku pencegahan penyakit difteri, pertusis dan tetanus. Setelah itu proses mencoba perilaku (trial) yang artinya ibu mencoba untuk melakukan tindakan perilaku pencegahan penyakit difteri, pertusis dan tetanus yang didasarkan atas berbagai pertimbangan yang telah dipikirkan sebelumnya hingga beradaptasi dengan perilaku (adaption), yaitu ibu mulai terbiasa untuk melakukan perilaku pencegahan penyakit difteri, pertusis dan tetanus (Notoatmodjo, 2007).

\section{PENUTUP}

\section{Kesimpulan}

Berdasarkan hasil analisis dan pembahasan penelitian, maka dapat diambil kesimpulan mengenai hubungan tingkat pengetahuan ibu tentang imunisasi DPT pada bayi dengan perilaku pencegahan penyakit difteri, pertusis dan tetanus di Puskesmas Korpri Bandar Lampung tahun 2020 sebagai berikut:

Diketahui ibu dengan pengetahuan buruk sebanyak 9 orang $(9.7 \%)$ dan ibu dengan pengetahuan baik sebanyak 84 orang $(90.3 \%)$ 
Diketahui ibu dengan perilaku buruk sebanyak 35 orang (37.6\%) dan ibu dengan perilaku baik sebanyak 58 orang $(62.4 \%)$.

Diketahui terdapat hubungan yang bermakna tingkat pengetahuan ibu tentang imunisasi DPT dengan perilaku pencegahan penyakit difteri, pertusis dan tetanus di Puskesmas Korpri Bandar Lampung tahun 2020 dengan nilai p-value $=0,024(\mathrm{p} \leq 0,05)$.

\section{Saran}

Berdasarkan penelitian yang telah dilakukan maka saran dari peneliti sebagai berikut:

Bagi Masyarakat. Hasil penelitian ini dapat dijadikan sumber ilmu pengetahuan untuk menambah informasi tentang hubungan tingkat pengetahuan ibu tentang imunsiasi DPT dengan perilaku pencegahan penyakit difteri, pertusis dan tetanus.

Bagi Institusi, hasil penelitian ini dapat dijadikan salah satu referensi untuk menambah wawasan serta ilmu pengetahuan terutama bagi mahasiswa prodi pendidikan dokter di fakultas kedokteran Universitas Malahayati tentang hubungan tingkat pengetahuan ibu tentang imunisasi DPT dengan perilaku pencegahan difteri, pertusis dan tetanus.

Bagi peneliti selanjutnya, hasil penelitian ini diharapkan dapat dijadikan acuan untuk penelitian lebih lanjut dengan variabel yang lebih bervariasi seperti faktor-faktor lain yang dapat mempengaruhi tingkat pengetahuan dan juga mengambil jumlah sampel penelitian yang lebih besar agar hasil penelitian lebih representatif.

\section{UCAPAN TERIMA KASIH}

Peneliti mengucapkan terima kasih kepada tuhan Yang Maha Esa yang telah memberikan rahmat dan pertolongannya sehingga penelitian ini dapat berjalan dengan lancar.

\section{DAFTAR PUSTAKA}

Anggraeni, A. 2015. Hubungan Tingkat Pengetahuan Ibu tentang Imunisasi Dasar Lengkap Anak dengan Kepatuhan Melaksanakan Imunisasi. Skripsi. Fakultas Kedokteran Universitas Bandung. Bandung

Aprida, S., Utami, S., \& Hasneli, Y. 2015. Efektifitas Pendidikan Kesehatan tentang Imunisasi Tetanus Toksoid (TT) Terhadap Pengetahuan Ibu Hamil tentang Imunisasi TT. Jurnal Online Mahasiswa Program Studi Ilmu Keperawatan Universitas Riau, 1(2), 1-9.

Bofarraj, M. A. 2011. Knowledge, attitude and practices of mothers regarding immunization of infants and preschool children at Al-Beida City, Libya 2008. Egyptian Journal of Pediatric Allergy and Immunology (The), 9(1).32-33

Hidayat, A.A. 2008. Pengantar Ilmu Kesehatan Anak. Jakarta: Salemba Medika. 
Dinas Kesehatan. 2015. Profil Kesehatan Provinsi Lampung tahun 2015. Lampung: Dinkes Provinsi Lampung.

Kemenkes RI, 2013. Profil Kesehatan Indonesia. Jakarta Kementrian Kesehatan RI.

Muryani, M., Machfoedz, I., \& Hasan, M. N. 2013. Tingkat Pengetahuan Ibu tentang Difteri Berhubungan dengan Perilaku Pencegahan Penyakit Difteri di Dusun Ngrame Kasihan Bantul. Jurnal Ners dan Kebidanan Indonesia, 1(2), 61-65.

Mustari, N. 2013. Gambaran Karakteristik Demografi Ibu Hamil Terhadap Kepatuhan Melakukan Imunisasi Tetanus Toxoid Ii Di Puskesmas Mangasa Kota Makassar. Jurnal Ilmiah Kesehatan Diagnosis, 3(1), 92-97.
Notoatmodjo, S. 2007. Promo Kesehatan dan Ilmu Perilaku. Jakarta: Rineka Cipta.

Notoatmodjo, S. 2007. Promo Kesehatan dan Ilmu Perilaku. Jakarta: Rineka Cipta.

Notoatmodjo, S. 2013. Promosi kesehatan dan perilaku kesehatan. Jakarta: Rineka Cipta.

Pusdatin Prov. Lampung. 2014. Ringkasan Eksekutif Data Dan Informasi Kesehatan Provinsi Lampung. Bandar Lampung : Pusdatin 2014.

Wawan, A dan Dew. 2010 Teori dan Pengukuran Pengetahuan, Sikap dan Perilaku Manusia. Yogyakarta: Nuha Medika 